\title{
Peacebuilding Strategies in Conflict Societies Through Art Education: Cyprus
}

\section{Estrategias de consolidación de la paz en sociedades en conflicto a través de la educación artística: Chipre}

\author{
Fatma Miralay \\ Department of education al Programs and Instruction Near East University, North Cyprus, Via \\ Mersin 10, Turkey. \\ ORCID: https://orcid.org/0000-0003-1085-4141
}

Received 01-12-20 Revised 01-25-20 Accepted 04-13-20 On line 06-29-20

*Correspondence

Email: fatma.miralay@neu.edu.tr
Cite as:

Miralay, F. (2020). Peacebuilding Strategies in Conflict Societies Through Art Education: Cyprus. Propósitos y Representaciones, 8 (SPE2), e795. Doi: http://dx.doi.org/10.20511/pyr2020.v8nSPE2.795 


\section{Summary}

The purpose of this study is to include the evaluation of teacher opinions concerning the acquisition of peace culture by students through art education programs applied in Northern and Southern Cyprus. The study is patterned according to qualitative research method and is performed with focus group interview. The research included 10 secondary school (K12) $7^{\text {th }}$ grade visual arts course teachers in total form both Northern Cypriot Turkish community $(n=5)$ and Southern Cypriot Greek community $(n=5)$. In the study, semi-structured interview form was used in obtaining the opinions of teachers. Teachers stated that they believed that acquisition of peace culture awareness by students through art education which would result in individual and social peace. They also displayed that families had a very important role to play in the popularization of peace culture through art education and that school administration and ministries were determinant in this respect. In addition, teachers added that in both communities education institutions did not play their part adequately in the popularization of peace culture in education.

Keywords: peace culture, education programs, art education, visual arts course, Cyprus.

\section{Resumen}

El propósito de este estudio es incluir la evaluación de las opiniones de los profesores sobre la adquisición de la cultura de paz por parte de los estudiantes a través de programas de educación artística aplicados en el norte y sur de Chipre. El estudio está estructurado de acuerdo con un método de investigación cualitativa y se realiza con una entrevista de grupo focal. La investigación incluyó a 10 profesores de cursos de artes visuales de séptimo grado de secundaria (K12) en total, tanto de la comunidad turca chipriota del norte $(n=5)$ como de la comunidad griega chipriota del sur $(n=5)$. En el estudio se utilizó la forma de entrevista semiestructurada para obtener las opiniones de los profesores. Los maestros declararon que creían que la adquisición de conciencia de la cultura de paz por parte de los estudiantes a través de la educación artística daría como resultado la paz individual y social. También mostraron que las familias tenían un papel muy importante que jugar en la popularización de la cultura de paz a través de la educación artística y que la administración y los ministerios escolares eran determinantes en este sentido. Además, los docentes agregaron que en ambas comunidades las instituciones educativas no cumplieron adecuadamente su papel en la popularización de la cultura de paz en la educación.

Palabras clave: cultura de paz, programas de educación, educación artística, curso de artes visuales, Chipre.

\section{Introduction}

Today violence and terror has spread to every faculty of life, and it is believed that peaceful resolution of conflicts and its popularization among societies is essential (Zembylas \& Bekerman 2017). Popularisation of peace consciousness begins in the individual, and producing effective peaceful solutions is only possible with the initiatives of individuals (Zembylas 2012; Apaydin \& Aksu, 2012). At this point, experts claim that peace consciousness in individuals begins at early ages and emphasize that it has to be a lifelong exercise (Bekerman \& McGlynn 2017; Song, 2012; Zembylas, 2007). This case creates the requirement of conveying an education -based peace culture to students and implicates that it can represent a starting point in social change. For example, the report published by UNESCO in 2011 emphasizes that "conflicts in the whole world have damaged and made education suffer considerably. However, education must be a key mechanism in the sustainability of inequalities and creation of peace phenomenon". Based on this opinion, it is witnessed that the re-conciliatory role of education in the existing inequality environment comes to the fore and it can be said that it has a potential for ensuring that peace culture is spread to the masses through education . 
In addition, it is stated in the literature that peace phenomenon can be possible with school environment, equipped education ists and education programs (Wulf, 2013). Likewise, some studies reveal that acquiring peace culture to individual in early ages can be ensured through education systems (Heather, 2013). For example, Harris (2012) asserts in his study that acquiring, developing and internalizing peace culture in societies can be possible with the value given to education . Harris (2012) also found out that basic education systems are widely seen as academically successful, but that some studies show that violent tendencies at schools are still ongoing.

In the light of this information, it is understood that an education -based peace culture perception has to be given to the students especially in school environments. From a different viewpoint, studies in the field of education sociology imply that conflicts are necessary elements for social change and development (Ültanır, 2003; Bar-Tal \& Rosen, 2009; Hürsen \& Miralay, 2016). An examination of the relevant literature shows that some experts display different opinions and suggestions on the topic. For example, Guetta (2013) recommends in his study that updated technological devices should be used in order to carry peace culture to different settings and share. On the other hand, Verwoord (2010) conducted a study on the configuration of peace culture and emphasized the importance of deepening of democratic areas in education models at schools, prevention of unfair elements and acquisition by students of a future-oriented and positive viewpoint. Darder (2017) examine the relation between peace culture and education with a similar approach and recommended that course programs with peace education content should be introduced to the students at school for a start. In addition, the author remarks that especially in recent years there were a variety of approaches in the popularization of peace culture awareness in education . For example, Haavelsrud and Stenberg (2012) stated that peace culture in education could be given to students with different methods and contents and that the emphasis should be on the communication skills, conflict-resolution skills and peaceful opinions of individuals. As an alternative suggestion to this opinion, they suggest that student groups from different cultures should be brought together and a discussion should be organized on a common topic. In a similar study, Bajaja and Chiu (2009) showed that peace culture in education could be integrated in all disciplines of art education with different disciplines such as human rights, security education, environmental education, and life sciences.

At this point, it can be claimed that peace culture in recent years has been discussed with different approaches and opinions and that, for a democratic and humanist viewpoint of society, art education has a special place in conveying peace culture awareness to students (Lederach \& Appleby, 2010). An examination of the literature shows that several studies have focused on art educaton in the conveying of peace culture to students (Miralay, 2017; Miralay \& Hürsen 2016; Ishaq, 2007; Glenn, 2011). For example, Bajaja and Hantzopoulos (2016) showed that characteristics which require adherence to freedom, creativity and ethical ideals is essential in the popularization of peace culture. In addition, he displayed that the acquisition of characteristics which require freedom, creativity and adherence to ethical ideals by individuals is important for the popularization of peace culture. He also stated that coverage of this topic in art education facilitated the transition of societies from mono-culturalism to multi-culturalism. Cabedo-Mas et al. (2017) mentioned the mission and vision of art education and revealed the organic connection of including peace culture phenomenon in art education programs. They indicated that this topic has a mission of bringing together different communities regardless of their religion, language, race and ethnic origin.

Vartanyan, (2012) underlined that art education facilitated the flourishing of peace environment in the future and that individuals gained positive perceptions with aesthetic experiences. Especially the artistic production process facilitates flexible thinking and staying strong in the face of negative developments as an essential element in dealing with conflicts. 
Azcona (2010) defines art education as an affective field based on anthropological, historical, cultural and similar fields which nourishes the ability of autonomous thinking. In addition, he believes that art education will allow for creating a pedagogical infrastructure, a common cultural ground in education, and developing a vision for common life through cultural values.

As can be understood from the information given above, it can be claimed that peace culture awareness can be conveyed through education starting from young generations using art education, which has a vital impact on societies. In this context, it can be claimed that acquisition by students of peace culture phenomenon with art education teaching programs will make contribution to the Cypriot problem from a different perspective for both communities. An examination of the studies in the literature conducted in the entire Cyprus, it becomes evident that it is mostly the civil society organization which make contribution to the popularization of bicommunal peace culture awareness. For example, the POST research institute and Association for Historical Dialogue and Research (AHDR) which are located in the Buffer Zone perform studies on non-violent, peace culture-based approaches in education system. In addition, the "bicommunal education committee" established under the presidencies of both Northern and Southern Cyprus is known for its efforts to popularize peace culture in education .

As regards scientific studies, no research activities are identified which correlated art education and peace culture. It is observed that these studies are mostly related to teacher perception, pedagogy, history courses, and conflict and ethnic group topics (Bekerman \& Zemblyas, 2016; Loukaidis \& Zembylas, 2016).Likewise, when the literature is examined, no scientific studies are identified which correlated art education and peace culture in the entire island. It is believed that a study which would cover this topic would add a new dimension to the field. In addition, it is believed that by correlating art education and peace culture, the acquisitions of students can be maximized and the problems experienced by teachers in the process can be identified. In accordance with the findings obtained in this study, it is believed that teachers can convey peace culture to students through art education which can provide a useful basis for further research in the field. Based on this finding, the purpose is to ensure that visual arts course of classroom education which is applied at the secondary education stage in Northern and Southern Cypriot communities can convey peace culture awareness to students and to evlauate teacher opinions so as to display the existing situation. Within this study, answer is sought to the following questions concerning the purpose of the study;

1. What is the importance of the topic of peace culture as a part of visual arts course curricula? Should this topic be covered only in societies which suffer from conflict?

2. To what extent should peace culture themed topics be covered in visual arts course curricula? What is its impact and importance on students?

3. What is the role of teachers, education managers and families in the acquisition of peace culture by students within the framework of art education?

\section{Methodology}

This research covers the evaluation of the role of art education programs implemented at secondary school $7^{\text {th }}$ grade (K12) in Northern and Southern Cyprus in the acquisition of peace culture awareness by students according to teacher opinions. In line with this objective, research data were obtained using focus group interview which is a qualitative research method. Focus group interview is expressed as an interview technique which focuses on a certain topic using a qualitative research method (Barlagne et al. 2017). In the study, semi-structured interview form was used to obtain teacher opinions which was developed by the researcher. Semi-structured interview helps obtaining in-depth information on a certain topic and avoids the limitations imposed by tests and surveys based on writing and filling-in with its standards at a certain level and flexibility (Yıldırım \& Şimşek, 2006). For this reason, focus group interview was considered 
and questions were prepared as short, clear and open as possible by limiting their number to 3 or 4 ( Kruger \& Casey, 2000, p. 42-43).

\section{Participants}

The sample of the study consists of 10 visual arts teachers in total who taught at the $7^{\text {th }}$ grade of secondary education (K12) in northern and southern Cypriot communities. Considering the political status of the island, convenience case sampling was preferred among purposive sampling methods in determining the participants. The research was conducted on $5(n=5)$ visual arts course teachers from Northern Cypriot community and $5(n=5)$ visual arts course teachers from Southern Cypriot community. Table 1 gives the demographic features of teachers in detail.

Table 1. Demographic information on the teachers

\begin{tabular}{ccccc}
\hline & \multicolumn{2}{c}{ Turkish Cypriot Teacher } & \multicolumn{2}{c}{ Greek Cypriot Teacher } \\
\hline Gender & Frequency(f) & Percentage $(\%)$ & Frequency(f) Percentage(\%) \\
\hline Male & 4 & 40 & 6 & 60 \\
Female & 6 & 60 & 7 & 70 \\
Age & & & & \\
$31-45$ & 2 & 20 & 3 & 30 \\
$36-40$ & 3 & 30 & 2 & 20 \\
$41-45$ & 5 & 50 & 8 & 80 \\
Educational Status & & & & \\
B.A & 7 & 70 & 5 & 50 \\
M.A & 2 & 20 & 7 & 70 \\
PhD & 1 & 10 & 1 & 10 \\
Professional Seniority & & & & - \\
\hline 6-10 year & - & - & 2 & 30 \\
11-15 year & 2 & 20 & 3 & 70 \\
16-20 year & 5 & 50 & 7 & 10 \\
Up to 21 & 2 & 20 & 1 & \\
\hline Total & 5 & 100 & 5 & \\
\hline
\end{tabular}

An examination of Table 1 reveals the demographic information on Cypriot Greek and Cypriot Turkish teachers. When the genders of all teachers who participated in the study are examined, it can be seen that they mostly consist of female teachers (60-70\%) and that they are between the ages of 41 and 45 (40\%-80\%). As regards education status, the number of teachers with graduate degree is higher among Cypriot Greek teachers $(70 \%)$ whereas among Cypriot Turkish teachers undergraduate degree-holders are in majority (70\%). An examination of seniority of teachers shows that professional seniority in both communities varies between 16 and 20 years $(50-70 \%)$.

\section{Data Collection Instruments}

In this study, the opinions of teachers are sought concerning the role of visual arts curricula of art education applied at $7^{\text {th }}$ grade of secondary education (K12) in Northern and Southern Cypriot communities on the acquisition of peace culture awareness among students. In accordance with this objective, semi-structured interview form was prepared by the researcher for teachers who serve at both communities. The development stages of the interview form prepared for teachers is explained in detail below. 


\section{Teachers' Interview Forum}

The interview form developed within the study was primarily prepared in order to determine the opinions of teachers working in both communities as regards the acquisition of peace culture awareness by students using art education. Within this objective, a semi-structured interview form was prepared for visual arts course teachers who serve in Northern and Southern Cypriot communities. First, at the preparation stage of the form literature search was conducted using the following words and phrases: peace culture, conflict, visual arts course, and education. Later, studies published on peace culture awareness at national and international level were analyzed and effort was paid to identify research in the place of peace culture in education in Northern and Southern Cypriot communities. The interview form which was designed in order to apply in the study consisted of two sections. In the first section which consists of demographic information on the teachers in both communities, the gender, age, education status and professional seniority of teachers were questioned. While preparing the semi-structured interview form questions, opinions of 3 civil society organizations and 5 visual arts course teachers that conducted studies on the popularization of peace culture in both societies were consulted. A pool of items was produced in light of the data obtained as a result of the interviews and literature search conducted. Later, necessary corrections were made to the questions based on the interviews with 5 visual arts experts and 1 specialist on curriculum development in education who served in both communities. The interview form was designed to include 7 items and a re-evaluation was made concerning scope and appropriateness to the field. As a result of the corrections provided by expert opinions, 4 items which were considered unnecessary were excluded form the form and the interview form consisted of 3 open-ended questions in the end.

In order to provide scope validity of the interview form, preliminary application was made to 4 Cypriot Turkish and 4 Cypriot Greek visual arts course teachers and the obtained data were analyzed. The interview form which wuld be applied to teachers serving in both communities was prepared in English which was the common language of both societies. The writing language of the interview form was prepared by 2 translator whose native language were English and Turkish respectively. In the translation, traditional approach method was used and the expressions which were prepared in Turkish in the first stage were translated to English language which is the language of the target group. Then, these translations were translated back to Turkish language and the language validity between the two translations was identified. In addition, the meaning alignment between two translations was checked in this process and the expressions were tested by 4 experts who spoke both languages.

\section{Data Analysis}

Descriptive data analysis technique among qualitative data analysis techniques was used in the analysis of data obtained from focus group interviews performed with the teachers. According to the descriptive analysis technique, obtained data are summarized and interpreted according to a preset conceptual framework or themes. The data can be organized according to the themes displayed by the questions or presented considering the questions or dimensions used in observation processes (Yıldırım \& Şimşek 2006). In this regard, records and notes obtained from the teachers were systematically described and documented by the researcher. Then, following the analysis steps used in descriptive analysis method, the obtained data were separated into themes and written. Based on the research questions and interview data concerning the topic, these themes were identified as the role of peace culture in education, course contents, increasing the sensitivity of the society for peace culture, and the roles of managers and families in the popularization of peace culture. Later, the general framework of the conducted data analysis was prepared. The obtained data concerning these themes were determined and described and brought together according to their harmony in terms of meaning. Then, the opinions of all teachers were examined and the frequency of every opinion was organized into tables. In order to ensure 
reliability in the study, focus group interview was conducted based on voice-recording. The records were transcripted on computer and transformed into texts. These data were coded separately by the researcher and an assistant. The codings were compared to evaluate their consistency. As a result, it was seen that there is high level of consistency between the researcher and the assistant and the coding was reliable. Within the process of the research, transcripted records and research results were confirmed by the participants. As regards transferability, data were organized according to the concepts and themes and the presentation of findings was supported with direct quotes under the tables. In terms of the verification of the research, documents and records were kept concerning all research processes (Yıldırım and Şimşek, 2013). In addition, each teacher was given a code number consisting of maximum three characters and, in order to make sure that the research is ethical, T.C.T. symbol was used for Cypriot Turkish teachers and G.C.T. symbol was used for Cypriot Greek teachers. In addition, in order to discriminate among number of teachers, numbers between 1 and 10 were added to each code additionally (TCT.1,GCT.2).

\section{Ethical aspect of the study}

Before beginning with the application, participant candidate teachers in both communities were reached through phone by the researcher so that the study could be conducted. The selection of participants in the study was based on voluntarism; however, researcher gave information to the participants through e-mail verbally and orally concerning the objective and content of the study. Then, the consent of the participants was obtained and detailed information was provided concerning confidentiality, coding of the names of participants, and voice recording only upon clear consent of the participants.

\section{Implementation}

The implementation stage of the research was conducted with 10 visual arts course teachers, 5 each from Northern and Southern communities. Krueger and Casey (2015) stated that ideal number of participants in focus group interview and that the number of sessions can vary between 1 and 3.

Prior to the application stage of the focus group interview, the researcher communicated the teachers serving in both communities through phone and e-mail. Later, an e-mail was sent to the teachers including instructions as to the objective of the study which explained that the research was based on voluntarism. Then, positive feedbacks sent by teachers were evaluated and 5 visual arts teachers from Northern and Southern communities each stated that they accepted to participate in the study. Following the feedbacks, the date and hour of the the focus group interview which was planned with teachers was decided through e-mail. For sensitivity towards both communities, the venue of the focus group interview was chosen as the Home for Cooperation which is located in the Buffer Zone of Nicosia.

On the application day, researcher arrived at the venue of the session and made the necessary preparations. Then, she welcomed the teachers and conducted a brief chat. The session was launched by the researcher and an assistant by presenting the information concerning the objective of the study. First of all, in accordance with ethical rules, it was explained to all participants that the interviews throughout the session would be recorded with voice recorders and their approval was obtained. Then, the participants were made to sit in a "U" form and each teacher was asked to introduce herself. Later, the questions in he interview form were read by the researcher in order and conveyed to the participants. In the meantime, the assistant distributed papers including interview questions to the participants. The questions were directed to the 
participants by a researcher and opened to discussion. The interview was based on question and answer and three questions were directed to all teachers which went from general to specific. Attention was paid to ensure that the questions were in the form of daily chat and usage style and the data obtained in the interview were recorded in writing by the researcher. The interviews took 60-90 minutes in total and completed in a single session. After the completed focus group study, the notes taken by each participant teacher and interview forms were collected by the assistant.

\section{Findings}

In this section, the findings obtained from the opinions of Cypriot Turkish and Cypriot Greek teachers on the acquisition of peace culture awareness by students through visual arts course curricula are presented. In this regard, the findings obtained from teacher opinions are organized and presented according to the sub-objectives of the study.

\section{Opinions of teachers concerning the importance of visual arts course and peace culture awareness}

In addition to the opinions of Cypriot Turkish and Cypriot Greek teachers on the importance of peace culture topic within visual arts course, another objective of the study is to identify the necessity of its application in conflict-ridden societies. While determining the opinion of teachers concerning the topic, effort was paid to identify the roles of teachers at this point and its reflections to the society. Qualitative data obtained from the study were analyzed and themed and presented in Table 2 by ordering from the highest to lowest frequency.

Table 2. Opinions of Teachers concerning the importance of the topic of peace culture through visual arts

\begin{tabular}{|c|c|c|}
\hline No & Themes & Frequency (f) \\
\hline 1 & The importance of peace culture topic in education and teaching programs & 5 \\
\hline 2 & Peace culture topic and the role of students & 4 \\
\hline 3 & $\begin{array}{c}\text { The importance of events and activities at schools in the popularization of peace } \\
\text { culture }\end{array}$ & 1 \\
\hline Total & & 10 \\
\hline
\end{tabular}

According to the data presented in Table 2, teacher opinions were supported with direct quotes and interpreted below.

In this part of the study, teachers emphasized the importance of peace culture in education curricula in addition to visual arts courses. Teachers stated that peace culture topics in education should not only be directed towards conflict-ridden societies, and stated that through education individuals would gain sensitivity in positive direction and the ability to make empathy. They mentioned the importance of directing students at schools as regards this topic and the possibility of making contribution to the development of humanist personality with this type of education understanding. In addition, it was displayed that in education it was possible that peace culture could be included in school environments and to convey it to wide masses in the society. Likewise, teachers stated that it would create young generations with developed peace consciousness. Quotes from teacher opinions are given below:

K.T.Ö.2: 'Including the topic of peace culture in education will make sure that pacifism is internalized as a life style." 
K.R.Ö.3: "Including peace culture topic in courses will create a huge and positive impact on students and claim an important place in the building of the future of the island."

K.T.Ö.5: "Peace education must have a place in all education systems. In this sense, the opinions, thoughts and ideals of students will improve."

K.R.Ö.2: "Peace education has to be included in all teaching programs; it must also be applied in groups. People who will be gathered from outside the school must also be included in peace culture studies."

K.T.Ö.1: 'Peace culture topics in education must be applied especially in life sciences courses beginning from early ages in the context of humanism and human rights and some activities must be performed."

A different group of teachers displayed the roles of teachers in the popularization of peace culture through art education. Teachers stated that students has a wide place in the society and argued that peace culture would add impetus to the education system in general not only with art education but also with student factor. In addition, they stated that education systems in the world could convey their studies on peace culture to wide masses through student cooperation. In addition, they made definitions implicating that democratic life could be formed permanently with students. Quotes from teacher opinions are given below:

K.T.Ö.4.'Including peace topics in art education especially will first make positive differences in individual relations of the students and reflect it to the environment."

K.R.Ö.5: "The high number of students in the society ensures that peace culture awareness is reflected to the society. In audition, encouragement of the teachers in this respect will save the education system from its bulky structure."

K.T.Ö.3: 'I think that students adopt a conveyor role in the popularization of peace culture with the topics which will be covered in art course as they will set an example to the world with their young vision and contemporary opinions."

K.R.Ö.4: "Making the students draw peace education topics in this course is invaluable for the society. Why? Because students will create works with their positive energy and enthusiasm and will be able to reach all segments of the society in the future, especially their peers."

With a different viewpoint, one teacher suggested that bi-communal activities should be performed on peace culture as a part of art education :

K.R.Ö.1: "' I think that platforms should be formed in Cyprus for all students and effort should be paid to realize it on a global scale. Performing artistic activities by students in both communities will make contribution to the solution process."

\section{Opinions of teachers on including subjects with peace culture theme in visual arts course and its impact on students}

The objective of this part of the study is to make the teachers include topics with peace culture theme in visual arts courses and determine its future impacts on students. When determining the opinions of teachers as regards course topics, the tasks of students in this regard and their relation with the community was also questioned the data obtained from the research were analyzed and themes and presented in Table 3 ordering from the one with the highest frequency to the one with the lowest frequency. 
Table 3. Opinions of teachers on including peace culture-themed topics in visual arts course and its impact on students

\begin{tabular}{ccc}
\hline No & Themes & Frequency (f) \\
\hline $\mathbf{1}$ & Peace culture topic should be covered in all courses & $\mathbf{4}$ \\
$\mathbf{2}$ & Providing effectiveness of peace culture awareness through artistic activities & $\mathbf{3}$ \\
$\mathbf{3}$ & The characteristics that an education curriculum should possess to apply peace & $\mathbf{3}$
\end{tabular}

Total

According to the data presented in Table 3, teacher opinions were supported with direct quotes and interpreted below.

All teachers who participated in the study stated that topics which would convey peace culture in education would be included in not only art education but in all courses. Teachers highlighted that conveying peace themed-topics with art education was of considerable importance and displayed the positive reflections of the topic on the society. In addition, they stated that studies should be conducted on the topic in every course and peace perception could be created in the society through students. Quotes from teacher opinions are as follows:

K.T.Ö.1: 'Peace culture can be taught not only in drawing course but within every topic. Peace should not be handled in terms of cultural, ethnic or political conflicts."

K.R.Ö.1: "' Popularization of peace culture with art education is more effective compared to other courses and it is more easy to reach the society through exhibitions".

K.T.Ö.4: 'Making students make peace-themed works in drawing courses will have positive impact on peace culture. But this effort must be supported with such courses as history and literature."

K.R.Ö.3: "It must definitely be included in every course topic. Topics with peace content given in art education will motivate students and I think that it will support events in both communities."

A group of teachers shared the importance of cultural activities at the point of conveying peace phenomenon in today's school environment. Teachers mentioned its contribution to the development of students and the importance of bi-communal activities. Teachers argued that preliminary work should be performed as regards supporting projects and displayed the importance of the support of relevant ministries. Quotes from teacher opinions are given below;

K.T.Ö.2:"' I think that any activity with the theme of peace culture would be beneficial at schools. Ministries should allocate a serious budget for these activities."

K.R.Ö.2: "Bi-communal peace activities should be supported within the scope of art courses, but it is a precondition that ministries take the leading position."

K.T.Ö.3 "Peace culture must be included in course topics; but if they encounter problems and financial support at the point of activities, they remain on paper."

However, a group of teachers suggested that world history and art history courses should be included in teaching programs. Teachers believed that with this method students would acquire general culture, and defined the topic by giving examples from art history subjects. In addition, they made reference to the confrontation topics in historical process on the island. They underlined the positive aspects of including peace culture-themed topics in art education on students. Quotes from teacher opinions are given below:

K.R.Ö.4: " First of all, art history topics must be included in art courses. I think that especially Dadaist school examples and information such as Picasso-Guernica which cover social issues is essential, they are directly related to the peace culture." 
K.R.Ö.5: "With peace culture in education, students will create synergy in their opinions and face with cohabitation and the past."

K.T.Ö.5: "Topics with peace theme in drawing course will have a positive impact on the perception of students which will spread to the entire society. I think that peace-themed topic must be included in all course contents."

Opinions of teachers concerning the roles of teachers, education managers and families in the acquisition of peace culture by students through visual arts course

One of the objectives of the study was to determine the opinions of teachers concerning the roles of teachers, education managers and families in the acquisition of peace culture by students through visual arts course. Effort was also paid to identify the suggestions of teachers on the topic. Data obtained from the study are analyzed and presented in Table 4 by ordering form the lowest to the highest frequency.

Table 4. Opinions of teachers on the roles of teachers, education managers and families in the acquisition of peace culture by students through visual arts course

\begin{tabular}{ccc}
\hline No & Themes & Frequency (f) \\
\hline $\mathbf{1}$ & Performing peace culture-themed activities in cooperation with the school & $\mathbf{4}$ \\
$\mathbf{2}$ & The relation of peace culture awareness and state in education & $\mathbf{4}$ \\
$\mathbf{3}$ & The family factor and its relation to peace culture topic & $\mathbf{2}$ \\
\hline Total & & $\mathbf{1 0}$ \\
\hline
\end{tabular}

According to the data presented in Table 4, teacher opinions are supported with direct quotations and interpreted below.

All of the teachers who participated in the study stated that the contribution of art education in peace culture should begin in school setting, conveyed to the students and supported with activities. In addition, teachers claimed that activities based on the cooperation of school management and families would make contribution to the peace culture. They emphasized that families and school managers had huge responsibilities in this regard. They suggested that bicommunal activities should be performed based on the cooperation between school, family and ministry and expanded especially through media. Quotations from teacher opinions are given below:

K.R.Ö.1: 'Families, teachers and managers should provide support and encouragement in this area. Through ministry bi-communal projects should be launched and social media should be used".

K.T.Ö.5: " Family has the power of influencing the students; with art education students should open exhibitions in the buffer zone and find ways to break down the walls".

K.R.Ö.2:" Ministries should initiate a common project in this area and common projects should be performed in art course sin the north and the south. They must also be supported by families and managers."

K.T.Ö.1: ' School settings are essential for acquisition of peace culture by students and its popularization. There conveying peace themed-topics to students with education will create a positive atmosphere in the entire society."

A group of teachers took a different viewpoint and criticized the education policy at public schools. Criticizing the class hours of art education, teacher emphasized the negative 
phrases used in history and literature courses. It was stated that the pedagogical infrastructure of art and education should be combined to create a common culture in both communities and that the government should make policies in this direction. Quotations from opinions are given below;

K.T.Ö.3: " Conveying peace culture to students is more the task of government than schools and families. Students are fed with chauvinism in history and literature courses, but they take only two hours of art courses in a week."

K.R.Ö.5: "Managers and ministries in both communities must be aware that peace culture topics should be covered in art education. Lack thereof is unacceptable on an island like Cyprus."

K.T.Ö.4: " Development of the sense of a shared fatherland and shared life through ethical and cultural values is not only the task of students but the government."

K.R.Ö.4: " Pedagogical infrastructure in education must be examined. I do not know to what extent it is done in Cyprus but a shared peace culture must be created beginning with schools."

A group of teachers, on the other hand, emphasized that family input in peace culture should be increased. In addition to families and students, every individual has role to play, and everyone has huge responsibilities, especially education. Quotations from teacher opinions are given below;

K.T.Ö.2: "'In the north of the island people emigrated to different countries after 1974. social and cultural structure of citizens changed. I vote for the education of families along with students."

K.R.Ö.3: ' First of all, acquisition of peace culture by students begins at home. Considering the losses and traumas that families suffered after 1974, it is inevitable that they reflect it to their children. For this reason, if cooperation is made with families in terms of peace culture in the field of education, it will be more permanent and solid."

\section{Discussion and Conclusion}

This study examines the acquisition of peace culture by students through visual arts course programs under art education applied at secondary school stage in Northern and Southern Cyprus. It is concluded that teachers form both communities who participated in the study made similar definitions as regards the acquisition of peace culture by students in education and art education. The common themes in the definitions of teachers called attention and it was found out that they were similar in terms of constructive recommendations. Nevertheless, they stated that ministries and school managements had important responsibilities as regards the popularization of peace culture and that families and especially teachers could be determinant in this regard. In addition, in the study, it was emphasized that art education has the capacity and content that would bring individual and social peace. Similar to the findings of this study, Demir (2011) emphasized that peace culture education could support the development of individuals in a holistic manner and peace phenomenon related to education would become popular in the society. In addition, due to classical approach-focused education system, it was concluded that education institutions in both communities have not played their part in the popularization and teaching of peace culture. It has been found out that existing art education programs and government policies prove inadequate in terms of peace culture course contents.

Based on the teacher opinions obtained in the study, it was indicated that peace culture in art education should not only be applied in conflict-ridden societies. It has been displayed that especially societies like Cyprus which go through solution process need compulsory education programs which introduce peace culture that has to be followed. A similar study conducted by Fontana (2017) emphasized that education studies with the topic of acquisition of peace culture by students has to be included in universal education programs. In this context, this opinion supports the conclusion of the study. 
Teachers also emphasized hat art education conveyed students such skills as respect, equality, justice and democracy. In addition to transferring academic knowledge at schools, it was recommended that democratic education settings should be created, valuable individuals who will assume effective roles in the society are educated, and skills and attitudes which will spread peace culture are conveyed to the students through art education programs. In a similar study, Dietrich (2014) stated that conveying peace culture phenomenon begins in classroom settings and indicated that the topics which will be covered in art courses are determinant and guiding. This opinion supports the conclusions drawn form the research. Likewise, teachers in both communities underlined the inclusion of course programs and activities with peace culture themes at all education stages starting from pre-school period. Teachers at this point indicated the importance of conveying peace culture awareness to students at early ages and claimed that it would generate positive attitudes in their education life, social relations and daily life. Teachers underlined that conveying peace culture awareness at early ages through education would ensure that individuals develop humanist personality and that a pacifist generation will emerges in the future. In a similar study, Mardin (2012) emphasized that peace culture perception and even respect for differences can be conveyed to children at early ages through education. He claims that children have the tendency of teasing and excluding anyone who is slightly different from them, and that education methods with the purpose of developing peace culture and respect should be used starting from pre-school, even nursery school period.

In addition, the conclusions of the study emphasize the necessity of teaching peace culture in different courses and their contents through art education programs. Bjersted (2003) displayed that peace culture awareness could be conveyed through education to students using especially history and social sciences courses in several countries of the world and that the contents of these courses are consistent with several topics. For this reason, particularly through existing art education programs applied in both societies, peace culture can be efficiently applied in line with a philosophy which is reflected on all courses. In a similar study, Mokeyeva and Zakirova (2015), underlined the interdisciplinary harmony in education in the development of peace culture awareness in students. This opinion supports the conclusions obtained in the study.

Besides, teachers stated that education activities with peace culture content which can be attended by all stakeholders of education could have a positive impact on school settings and that bi-communal student platforms should be formed. Another conclusion obtained in the study is that in addition to teachers, families are also critical in conveying peace culture awareness to students. A similar study conducted by Jennings (2015) suggested that acquisition of peace culture by students is reinforced with the interaction of families and education setting and provides some recommendations on the development of joint programs in this regard. Ishaq (2007) conducted a similar study on conflict-ridden societies and stated that peace culture was reinforced by teachingeducation programs, ministries, school management and state policies. As a result, in this study Cypriot Turkish and Cypriot Greek teachers displayed the positive aspects of conveying peace culture awareness in visual arts course, especially in art education . In addition, they indicated that including peace culture awareness in different courses is an obligation. Likewise, teachers suggested that focusing on peace and culture visions in art education is possible and that support could be received from relevant stakeholders and a social ground could be provided for conveying peace culture to students through education .

\section{Recommendations}

1. It is recommended that peace culture topic in education should be covered in education programs in different disciplines applied in the entire island.

2. It is recommended that visual arts course curricula in both communities should be restructured so as to include peace culture awareness. 
3. It is recommended that course programs which will be related to peace culture should be evaluated by family, school managers, students and relevant stakeholders and their opinions should be consulted.

4. It is recommended that opinions of not only teachers who provide education but also students should be evaluated.

5. It is recommended that activities with the theme of peace education should be performed in schools in both communities and that the relations between both communities should be strengthened.

6. It is recommended that common activities should be performed at schools in Northern and Southern communities and student participation should be encouraged.

\section{References}

Apaydın, Ç., \& Aksu, M. (2012). Opinions of teachers concerning peace education . Inonu University Journal Of The Faculty Of education Special Issue, 13(3), 131-148.

Azcona, M. C. (2010). Peace education Through Literature. Peace Studies, PublicPolicy and Global Security-Volume III, 107.

Bajaj, M., \& Chiu, B. (2009). education for sustainable development as peace education . Peace \& Change, 34(4), 441-455.

Bajaj, M., \& Hantzopoulos, M. (Eds.). (2016). Peace education : International perspectives. Bloomsbury Publishing.

Barlagne, C., Cornet, D., Blazy, J. M., Diman, J. L., \& Ozier-Lafontaine, H. (2017). Consumers' preferences for fresh yam: a focus group study. Food science \& nutrition, 5(1), 54-66.

Bar-Tal, D., \& Rosen, Y. (2009). Peace education in societies involved in intractable conflicts: Direct and indirect models. Review of education al Research, 79(2), 557-575.

Bekerman, Z., \& McGlynn, C. (2017). Peace education in a Bilingual and Bi-ethnic School for Palestinians and Jews in Israel: Lessons and Challenges.

Bjerstedt, A. (2003). Developing Preparedness for Peace: Objectives, Methods, Difficulties and Possibilities in Peace-Related education . Peace education Reports.

Cabedo-Mas, A., Nethsinghe, R., \& Forrest, D. (2017). The role of the arts in education for peacebuilding, diversity and intercultural understanding: A comparative study of education al policies in Australia and Spain. International Journal of education \& the Arts, 18(11).

Darder, A. (2017). Dreaming of Peace in a Culture of War. Pedagogy, Politics and Philosophy of Peace: Interrogating Peace and Peacemaking, 97.

Demir, S. (2011). Outlook to Peace education in Turkey: Definitions, challenges, suggestions: A Qualitative Examination. education Sciences in Theory and Applications, 11(4), 17271745.

Dietrich, W. (2014). education for the Arts and the Peace (s). International Yearbook for Research in Arts education, 149-152.

Fontana, G. (2016). education policy and power-sharing in post-conflict societies: Lebanon, Northern Ireland, and Macedonia. Springer.

Glenn, W. J. (2012). Developing understandings of race: Preservice teachers' counter-narrative (re) constructions of people of color in young adult literature. English education , 44(4), 326-353.

Guetta, S. (2013). From peace education to culture of peace: context and issues. Studi sulla formazione, 16(1), 167-179.

Haavelsrud, M., \& Stenberg, O. (2012). Analyzing peace pedagogies. Journal of Peace education , 9(1), 65-80.

Harris, I. M., \& Morrison, M. L. (2012). Peace education . McFarland.

Hursen, C., \& Miralay, F. (2016). Similar Cultures, Similar Problems: Art education Programs in Northern and Southern Cyprus. International Journal of education al Sciences, 15(12), 14-26. 
Ishaq A (2007). Prosperity and peace through art. UNESCO Observatory on Multi Disciplinary Research on Arts education e-Journal, The University of Melbourne, v1 n1.

Jennings, P. A. (2015). Mindfulness for Teachers: Simple Skills for Peace and Productivity in the Classroom (The Norton Series on the Social Neuroscience of education ). WW Norton \& Company.

Krueger, R. A., \& Casey, M. A. (2010). Focus group interviewing. Handbook of practical program evaluation. 3rd edition. San Francisco (CA): Jossey-Bass.

Krueger, R. A., \& Casey, M. A. (2015). Participants in a focus group. Focus Groups A Practical Guide for Applied Research, edited by: Krueger, RA and Casey, MA, Sage Publications, Inc, USA.

Lederach, J. P., \& Appleby, R. S. (2010). Strategic peacebuilding: An overview. Strategies of peace: Transforming conflict in a violent world, 19-44.

Loukaidis, L., \& Zembylas, M. (2016). Greek-Cypriot teachers' perceptions of religious education and its contribution to peace: perspectives of (in) compatibility in a divided society. Journal of Peace education , 1-19.

Mardin, N, B. (2012). Peace education . [Peace education ]. Peace Culture and education Workshop. Istanbul, HTC Ofset.

Miralay, F. (2017). An Evaluation Based on Teachers' and Students' Opinions on Art Curricula in Northern and Southern Cyprus. Eurasia Journal of Mathematics, Science and Technology education, 13(10), 6853-6866.

Mokeyeva, E. V., Zakirova, V. G., \& Masalimova, A. R. (2015). Tolerant pedagogic space as a condition of non-violence position education among elementary school pupils. Review of European Studies, 7(4), 216.

Song, Y. I. K. (2012). Educating for peace: A case study of a constructivist approach to understanding peace through artistic expression. Creative education, 3(01), 79.

Verwoord, R. E. M. (2011). " Building Peace" through quiltmaking: the role of participatory artistic quiltmaking in supporting peacebuilding among grade 4-7 youth (Doctoral dissertation, University of British Columbia).

Wulf, C. (2013). Human development in a globalized world. education towards peace, cultural diversity and sustainable development. Revista española de pedagogía, 71-86.

Yıldırım, A., \& Şimşek, H. (2006). Qualitative research methods in social sciences. Seçkin Publications.

Yıldırım, A., \& Şimşek, H. (2013). Qualitative research methods in social sciences.(9. extended edition) Ankara: Seçkin Publications.

Unesco, I. C. T. (2011). Competency framework for teachers. Paris: United Nations education al, Scientific and Cultural Organization.

Ültanır, G. (2003). The Relationship Between education and Culture- The Worry as to What Cultural Dimensions are to be transmitted to the Young Generation in education . Gazi University Journal of Gazi education Faculty, 23(3).

Zembylas, M. (2007). The politics of trauma: Empathy, reconciliation and peace education . Journal of Peace education , 4(2), 207-224.

Zembylas, M. (2012). Pedagogies of strategic empathy: Navigating through the emotional complexities of anti-racism in higher education . Teaching in Higher education, 17(2), 113-125.

Zembylas, M., \& Bekerman, Z. (2016). Key Issues in Critical Peace education Theory and Pedagogical Praxis: Implications for Social Justice and Citizenship education . In The Palgrave International Handbook of education for Citizenship and Social Justice (pp. 265-284). Palgrave Macmillan UK.

Zembylas, M., \& Bekerman, Z. (2017). Some Reflections on Critical Peace education . Pedagogy, Politics and Philosophy of Peace: Interrogating Peace and Peacemaking, 147. 